\title{
Front Matter: Volume 8247
}

, "Front Matter: Volume 8247," Proc. SPIE 8247, Frontiers in Ultrafast Optics: Biomedical, Scientific, and Industrial Applications XII, 824701 (19 March 2012); doi: 10.1117/12.928256

SPIE. Event: SPIE LASE, 2012, San Francisco, California, United States 


\title{
PROCEEDINGS OF SPIE
}

\section{Frontiers in Ultrafast Optics: Biomedical, Scientific, and Industrial Applications XII}

\author{
Alexander Heisterkamp \\ Michel Meunier \\ Stefan Nolte \\ Editors \\ 22-25 January 2012 \\ Sponsored by \\ SPIE \\ Cosponsored by \\ Amplitude Systemes (France) \\ APE GmbH (Germany) \\ Published by \\ SPIE
}

San Francisco, California, United States

Volume 8247 
The papers included in this volume were part of the technical conference cited on the cover and title page. Papers were selected and subject to review by the editors and conference program committee. Some conference presentations may not be available for publication. The papers published in these proceedings reflect the work and thoughts of the authors and are published herein as submitted. The publisher is not responsible for the validity of the information or for any outcomes resulting from reliance thereon.

Please use the following format to cite material from this book:

Author(s), "Title of Paper," in Frontiers in Ultrafast Optics: Biomedical, Scientific, and Industrial Applications XII, edited by Alexander Heisterkamp, Michel Meunier, Stefan Nolte, Proceedings of SPIE Vol. 8247 (SPIE, Bellingham, WA, 2012) Article CID Number.

ISSN 0277-786X

ISBN 9780819488909

Published by

SPIE

P.O. Box 10, Bellingham, Washington 98227-0010 USA

Telephone +1 3606763290 (Pacific Time) · Fax +1 3606471445

SPIE.org

Copyright (C) 2012, Society of Photo-Optical Instrumentation Engineers

Copying of material in this book for internal or personal use, or for the internal or personal use of specific clients, beyond the fair use provisions granted by the U.S. Copyright Law is authorized by SPIE subject to payment of copying fees. The Transactional Reporting Service base fee for this volume is $\$ 18.00$ per article (or portion thereof), which should be paid directly to the Copyright Clearance Center (CCC), 222 Rosewood Drive, Danvers, MA 01923. Payment may also be made electronically through CCC Online at copyright.com. Other copying for republication, resale, advertising or promotion, or any form of systematic or multiple reproduction of any material in this book is prohibited except with permission in writing from the publisher. The CCC fee code is 0277-786X/12/\$18.00.

Printed in the United States of America.

Publication of record for individual papers is online in the SPIE Digital Library.

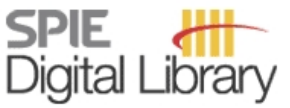

SPIEDigitalLibrary.org

Paper Numbering: Proceedings of SPIE follow an e-First publication model, with papers published first online and then in print and on CD-ROM. Papers are published as they are submitted and meet publication criteria. A unique, consistent, permanent citation identifier (CID) number is assigned to each article at the time of the first publication. Utilization of CIDs allows articles to be fully citable as soon as they are published online, and connects the same identifier to all online, print, and electronic versions of the publication. SPIE uses a six-digit CID article numbering system in which:

- The first four digits correspond to the SPIE volume number.

- The last two digits indicate publication order within the volume using a Base 36 numbering system employing both numerals and letters. These two-number sets start with 00, 01, 02, 03, 04, $05,06,07,08,09,0 A, 0 B \ldots 0 Z$, followed by 10-1Z, 20-2Z, etc.

The CID number appears on each page of the manuscript. The complete citation is used on the first page, and an abbreviated version on subsequent pages. Numbers in the index correspond to the last two digits of the six-digit CID number. 


\section{Contents}

vii Conference Committee

\section{SESSION 1 CELL MANIPULATION AND OPTOPORATION USING NANO- AND MICROPARTICLES}

824706 Nano particles insertion into individual mammalian cells using optical tweezers [8247-05] M. Waleed, J.-D. Kim, Y.-G. Lee, Gwangju Institute of Science and Technology (Korea, Republic of)

\section{SESSION 2 LASER FABRICATION OF SCAFFOLDS AND ARTIFICIAL BIOSTRUCTURES}

824708 Femtosecond laser two-photon polymerization of three-dimensional scaffolds for tissue engineering and regenerative medicine applications [8247-07]

V. Aprile, S. M. Eaton, M. Laganà, G. Cerullo, M. T. Raimondi, R. Osellame, Politecnico di Milano (Italy)

\section{SESSION 3 NONLINEAR LASER SURGERY AND IMAGING}

8247 OD Neuronal rat cell imaging using a new UV-extended supercontinuum source [8247-12] S. Taccheo, Swansea Univ. (United Kingdom); S. Soria, Istituto di Fisica Applicata Nello Carrara (Italy); C. D'Andrea, Politecnico di Milano (Italy); K. Schuster, Institute of Photonic Technology (Germany); A. Bassi, R. Cubeddu, Politecnico di Milano (Italy); J. Kobelke, K. Mörl, Institute of Photonic Technology (Germany); G. Nunzi Conti, G. Righini, Istituto di Fisica Applicata Nello Carrara (Italy); F. Quercioli, Istituto Nazionale Ottica (Italy)

\section{SESSION 4 ULTRASHORT LASER SYSTEMS FOR BIOMEDICAL}

8247 OF Alignment and maintenance free all-fiber laser source for CARS microscopy based on frequency conversion by four-wave-mixing [8247-14]

M. Baumgartl, Friedrich-Schiller-Univ. Jena (Germany) and Helmholtz Institute Jena (Germany); M. Chemnitz, C. Jauregui, Friedrich-Schiller-Univ. Jena (Germany); T. Meyer, B. Dietzek, J. Popp, Friedrich-Schiller-Univ. Jena (Germany) and Institut für Photonische Technologien e.V. (Germany); J. Limpert, Friedrich-Schiller-Univ. Jena (Germany) and Helmholtz Institute Jena (Germany); A. Tünnermann, Fraunhofer-Institut für Angewandte Optik und Feinmechanik (Germany) and Helmholtz Institute Jena (Germany) and Fraunhofer Institute for Applied Optics and Precision Engineering (Germany)

$82470 G$ Low noise laser system generating 26 -fs pulse duration, 30-kW peak power, and tunability from 800- to 1200-nm for ultrafast spectroscopy and multiphoton microscopy [8247-15] B. Resan, F. Brunner, A. Rohrbacher, H. Ammann, K. J. Weingarten, Time-Bandwidth Products AG (Switzerland) 


\section{SESSION $5 \quad$ ULTRAFAST LASER SYSTEMS AND MEASUREMENTS}

$8247 \mathrm{OH}$ High Q femtoREGEN UC laser systems for industrial microprocessing applications [8247-16]

V. V. Matylitsky, High Q Laser Innovation GmbH (Austria); P. Kubis, C. J. Brabec, Univ. Erlangen-Nürnberg (Germany) and ZAE Bayern (Germany); J. Aus der Au, High Q Laser Innovation GmbH (Austria)

8247 Ol Sub-picosecond laser amplifier with $>1 \mathrm{~mJ}$ pulse energy and 33W average power [8247-17] M. Delaigue, S. Ricaud, C. Hönninger, E. Mottay, Amplitude Systèmes (France)

8247 0J Measuring two ultrashort pulses simultaneously using a single device and on a single shot [8247-18]

T. C. Wong, J. Ratner, P. Vaughan, V. Chauhan, R. Trebino, Georgia Institute of Technology (United States)

8247 OK Pulse repetition interval-based Excess Fraction method for an arbitrary and absolute distance measurement using a femtosecond optical frequency comb [8247-19]

D. Wei, K. Takamasu, H. Matsumoto, The Univ. of Tokyo (Japan)

\section{SESSION $6 \quad$ PROCESSING OF TRANSPARENT MATERIALS I}

$8247 \mathrm{OL} \quad$ Femtosecond laser waveguide writing for integrated quantum optics (Invited Paper) [8247-20]

A. Crespi, Istituto di Fotonica e Nanotecnologie (Italy) and Politecnico di Milano (Italy);

L. Sansoni, Sapienza Univ. di Roma (Italy); G. Vallone, Museo Storico della Fisica e Ctr. Studi e Ricerche Enrico Fermi (Italy) and Sapienza Univ. di Roma (Italy); F. Sciarrino, Sapienza Univ. di Roma (Italy) and Istituto Nazionale di Ottica (Italy); R. Ramponi, Istituto di Fotonica e Nanotecnologie (Italy) and Politecnico di Milano (Italy); P. Mataloni, Sapienza Univ. di Roma (Italy) and Istituto Nazionale di Ottica (Italy); R. Osellame, Istituto di Fotonica e Nanotecnologie (Italy) and Politecnico di Milano (Italy)

8247 OM Femtosecond laser writing of polarization devices for optical circuits in glass [8247-21] L. A. Fernandes, Univ. of Toronto (Canada) and INESC Porto (Portugal); J. R. Grenier, P. R. Herman, J. S. Aitchison, Univ. of Toronto (Canada); P. V. S. Marques, INESC Porto (Portugal)

8247 ON Enhanced formation of nanogratings inside fused silica due to the generation of self-trapped excitons induced by femtosecond laser pulses [8247-22]

S. Richter, F. Jia, M. Heinrich, S. Döring, Friedrich-Schiller-Univ. Jena (Germany); S. Nolte, A. Tünnermann, Friedrich-Schiller-Univ. Jena (Germany) and Fraunhofer Institute of Applied Optics and Precision Engineering (Germany)

\section{SESSION 7 PROCESSING OF TRANSPARENT MATERIALS II}

$82470 Q \quad$ Formation dynamics of femtosecond laser-induced phase objects in transparent materials (Invited Paper) [8247-25]

A. Mermillod-Blondin, A. Rosenfeld, Max-Born-Institut für Nichtlineare Optik und Kurzzeitspektroskopie (Germany); R. Stoian, E. Audouard, Lab. Hubert Curien, CNRS, Univ. de Lyon (France) 
8247 OR Density variation in fused silica exposed to femtosecond laser [8247-26]

A. Champion, Y. Bellovard, Eindhoven Univ. of Technology (Netherlands)

8247 OT On the role of the scanning line density on the etching of fused silica specimens exposed to femtosecond lasers pulses [8247-28]

Y. Bellouard, Eindhoven Univ. of Technology (Netherlands); A. A. Said, M. Dugan, P. Bado, Translume, Inc. (United States)

8247 OU Structural modification in Er-Yb doped zinc phosphate glasses with megahertz repetition rate femtosecond pulses [8247-29]

N. Troy, L. B. Fletcher, Univ. of California, Davis (United States); S. T. Reis, R. K. Brow, Missouri Univ. of Science and Technology (United States); H. Huang, L. Yang, J. Liu, PolarOnyx, Inc. (United States); D. M. Krol, Univ. of California, Davis (United States)

\section{SESSION 8 PROCESSING OF TRANSPARENT MATERIALS III}

8247 0X Rapid prototyping of biocompatible sensor chips by picoseconds laser structuring of a platinum/ tantalum pentoxide thin film layer system [8247-32]

G. Heise, Munich Univ. of Applied Sciences (Germany); D. Trappendreher, Technische Univ. München (Germany) and Munich Univ. of Applied Sciences (Germany); F. Ilchmann, R. S. Weiss, B. Wolf, Technische Univ. München (Germany); H. P. Huber, Munich Univ. of Applied Sciences (Germany)

$82470 Z$ Mechanism of selective removal of transparent layers on semiconductors using ultrashort laser pulses [8247-34]

T. Rublack, S. Hartnaver, M. Mergner, M. Muchow, M. Schade, H. S. Leipner, Martin-Luther-Univ. Halle-Wittenberg (Germany); G. Seifert, Martin-Luther-Univ.

Halle-Wittenberg (Germany) and Fraunhofer Ctr. für Silizium-Photovoltaik (Germany)

SESSION 9 ULTRAFAST LASER 3D-FABRICATION: JOINT SESSION WITH CONFERENCE 8243

824710 Three-dimensional silver nanostructure fabrication through multiphoton photoreduction [8247-35]

K. Vora, S. Kang, S. Shukla, E. Mazur, Harvard Univ. (United States)

824711 Material specific effects and limitations during ps-laser generation of micro structures [8247-36]

J. Hildenhagen, U. Engelhardt, M. Smarra, K. Dickmann, Muenster Univ. of Applied Sciences

(Germany)

SESSION 10 FUNDAMENTALS AND DIAGNOSTICS IN ULTRAFAST LASER PROCESSING: JOINT SESSION WITH CONFERENCE 8243

824717 Influence of pulse duration on the hole formation during short and ultrashort pulse laser deep drilling [8247-42]

S. Döring, S. Richter, Friedrich-Schiller-Univ. Jena (Germany); A. Tünnermann, S. Nolte, Friedrich-Schiller-Univ. Jena (Germany) and Fraunhofer Institute for Applied Optics and Precision Engineering (Germany) 
824718 Supercontinuum emission from water using fs pulses in the external tight focusing limit [8247-45]

S. Sreeja, S. Venugopal Rao, Univ. of Hyderabad (India); P. Radhakrishnan, Cochin Univ. of Science and Technology (India); S. P. Tewari, P. Prem Kiran, Univ. of Hyderabad (India)

8247 1A Compact laser pulser for TOF SPAD rangefinder application [8247-47]

L. W. Hallman, Univ. of Oulu (Finland); K. Haring, L. Toikkanen, T. Leinonen, Tampere Univ. of Technology (Finland); B. S. Ryvkin, Univ. of Oulu (Finland) and loffe Physico-Technical Institute (Russian Federation); J. T. Kostamovaara, Univ. of Oulu (Finland)

8247 1C Directly diode-pumped femtosecond laser based on an Yb:KYW crystal [8247-49] G. H. Kim, J. Yang, D. S. Lee, A. V. Kulik, E. G. Sall', S. A. Chizhov, V. E. Yashin, U. Kang, Korea Electrotechnology Research Institute (Korea, Republic of)

8247 ID Development of an automatics joint-area-measurement system after ultrafast laser microwelding [8247-50]

Y. Nonogaki, K. Okusu, M. Yoshimoto, T. Tamaki, Nara National College of Technology (Japan)

Author Index 


\title{
Conference Committee
}

\author{
Symposium Chairs
}

Friedhelm Dorsch, TRUMPF Werkzeugmaschinen GmbH + Co. KG (Germany)

Alberto Piqué, U.S. Naval Research Laboratory (United States)

Symposium Cochairs

Bo Gu, IPG Photonics Corporation (China)

Andreas Tünnermann, Friedrich-Schiller-Universität Jena (Germany)

Conference Chairs

Alexander Heisterkamp, Friedrich-Schiller-Universität Jena (Germany) Michel Meunier, Ecole Polytechnique de Montréal (Canada)

Stefan Nolte, Friedrich-Schiller-Universität Jena (Germany)

Program Committee

Craig B. Arnold, Princeton University (United States)

James E. Carey III, SiOnyx Inc. (United States)

Xun Gu, Max-Planck-Institut für Quantenoptik (Germany)

Denise M. Krol, University of California, Davis (United States)

Eric Mazur, Harvard University (United States)

Michael M. Mielke, Raydiance, Inc. (United States)

Eric Mottay, Amplitude Systemes (France)

Christopher B. Schaffer, Cornell University (United States)

Alexander Szameit, Technion-Israel Institute of Technology (Israel)

Alfred Vogel, Universität zu Lübeck (Germany)

Wataru Watanabe, National Institute of Advanced Industrial Science and Technology (Japan)

Session Chairs

1 Cell Manipulation and Optoporation Using Nano- and Microparticles Alexander Heisterkamp, Friedrich-Schiller-Universität Jena (Germany)

2 Laser Fabrication of Scaffolds and Artificial Biostructures Michel Meunier, Ecole Polytechnique de Montréal (Canada)

$3 \quad$ Nonlinear Laser Surgery and Imaging

Georg von Freymann, Nanoscribe GmbH (Germany) 
$4 \quad$ Ultrashort Laser Systems for Biomedical

David Kleinfeld, University of California, San Diego (United States)

$5 \quad$ Ultrafast Laser Systems and Measurements

Michael M. Mielke, Raydiance, Inc. (United States)

6 Processing of Transparent Materials I

Michael Withford, Macquarie University Australia (Australia)

$7 \quad$ Processing of Transparent Materials II

Craig B. Arnold, Princeton University (United States)

$8 \quad$ Processing of Transparent Materials III

Alexandre Mermillod-Blondin, Max-Born-Institut für Nichtlineare Optik und Kurzzeitspektroskopie (Germany)

$9 \quad$ Ultrafast Laser 3D-Fabrication: Joint Session with Conference 8243

Yoshiki Nakata, Osaka University (Japan)

Beat Neuenschwander, Berner Fachhochschule Technik und Informatik (Switzerland)

10 Ultrafast Laser-induced Modification of Glasses or Transparent Materials: Joint Session with Conference 8243

Stefan Nolte, Friedrich-Schiller-Universität Jena (Germany)

11 Ultrafast Laser Surface Processing: Joint Session with Conference 8243

Beat Nevenschwander, Berner Fachhochschule Technik und Informatik (Switzerland)

Yoshiki Nakata, Osaka University (Japan)

12 Fundamentals and Diagnostics in Ultrafast Laser Processing: Joint Session with Conference 8243

Michel Meunier, Ecole Polytechnique de Montréal (Canada) 